\title{
Between Documentary and Fiction: Authenticity and Voyeurism in the Cinema of Ulrich Seidl
}

There is no doubt about the impossibility of making a clear distinction between documentary and fiction in cinema today. The coexistence of these two types of films and their mutual influences are obvious. It seems that this connection in recent years has become particularly close. One can observe the constantly expanding border area between the documentary and fictional film. Under the influence of new communication technologies and TV formats, new cross-genres have appeared, such as the docu-soap or docu-drama. These tendencies are observable also in the increasing popularity of mockumentaries, in which the documentary style is used to tell a fictional story. The Polish film director and screenwriter Jerzy Gębski even remarked that the feature and documentary film were Siamese twins. [1]

The words of Gębski describe very well the works of Ulrich Seidl. Their peculiarity lies in the fact that the Austrian director combines freely feature and documentary film techniques. This makes classifying his works not only impossible, but also pointless. Nevertheless, Seidl was perceived by critics as a documentary film director until he shot Dog Days (Hundstage) in 2001. This film is regarded as a turning point in his career, a transition from documentary to fictional filmmaking. In fact, it is hard to speak of a fundamental change in this instance. It seems more appropriate to perceive Seidl's work as the director's own consistently developed concept of cinema. He admits this himself in interviews. For example, he said the following in one such interview:

Generally I became interested in film late in life. At the age of 26 I started studying at the Vienna Film Academy. I didn't think about the genre - I wanted simply to make movies. Documentary and feature film are equally important to me. Besides, all my films up to now haven't been "pure" documentaries. In each of them I've crossed the boundaries between documentary and fictional film. Dog Days is the natural consequence of my artistic way.[2]

In an another interview, he declared, "Right from the start I didn't perceive myself as a documentary filmmaker. Documentary filmmaking was the easiest way to me to make movies at all." [3]

[1] Cf.: J. Gębski, "Kilka paradoksów o filmie dokumentalnym", Kwartalnik Filmowy 1998, no. 23, p. 130. [2] G. Wojtowicz, Rozmowa $z$ Ulrichem Seidlem, twórca filmu „Upały”, <http://stopklatka.pl//6654118,rozmowa-z-ulrichem-seidlem-tworca-filmu- upaly> (accessed: August 24th, 2013). Unless otherwise noted, all translations into English are my own. [3] C. Wulff, Welt ohne Mitleid, in: Gegenschuss: 16 Regisseure aus Österreich, ed. Peter Illetschko, Wespennest, Wien 1995, p. 243. 
Florian Lamp, an author of the monograph Die Wirklichkeit, nur stilisiert, on Ulrich Seidl's films, describes the elements of documentary filmmaking that can be found in the works of the Austrian film director. For this purpose, he uses a classification of the modes of documentary representation formulated by Bill Nichols in 2001. Nichols distinguishes six documentary sub-genres, which "set up conventions that a given film may adopt; and [...] provide specific expectations viewers anticipating having fulfilled." [4] These comprise poetic, expository, participatory, observational, reflexive and performative documentaries. Each of them "possesses examples that we can identify as prototypes or models: they seem to give exemplary expression to the most distinctive qualities of that mode."[5]According to Lamp, almost all of the documentary types mentioned by Nichols have influenced Seidl's works.[6]

The first model in Nichols' theoretical taxonomy is the poetic documentary. This model "stresses mood, tone, and affect much more than displays of knowledge or acts of persuasion. The rhetorical element remains underdeveloped." [7]The influence of this type of documentary on the Seidl's films has been significant. For example, Good News: Newspaper Salesman, Dead Dogs and Other People from Vienna (Good News: von Kolporteuren, toten Hunden und anderen Wienern, 1990) depicts Vienna in very subjective manner. Seidl combines various scenes with one another, from shots taken at a homeless shelter or veterinary clinic, to the apartments of the Viennese middle class. The creation of a specific mood is here more important than a coherent story. Furthermore, Nichols mentions city symphony films among his examples of poetic documentaries. At least two of the Seidl's films can be considered complex portraits of Vienna - the aforesaid Good News and also Dog Days.

Another model of documentary represented in Seidl's work is the participatory mode. Characteristic of this type is interaction between the filmmaker and the film's subjects. Nichols defines this model as follows: "We expect that what we learn will hinge on the nature and quality of the encounter between filmmaker and subject rather than on generalizations supported by images illuminating a given perspective. We may see as well hear the filmmaker act and respond on the spot, in the same historical area as the film's subjects." [8]The Austrian director considers himself as a continuator of this tradition. His film's subjects are aware of the camera's presence at all times. Interviews are also a very important part of his films. Lamp spotlights their very specific form. They are always one-sided. One cannot hear or see the director asking a question; the viewer observes only the subjects. They look straight into the camera, often introducing themselves and telling about particular

[4] B. Nichols, Introduction to Documentary, Indiana University Press, Bloomington 2001, p. 99.

[5] Ibidem, p. 99-100.

[6] Cf.: F. Lamp, Die Wirklichkeit, nur stilisiert. Die
Filme des Ulrich Seidl, Büchner-Verlag, Darmstadt 2009, pp. 13-14.

[7] B. Nichols, op. cit., p. 103.

[8] Ibidem, p. 116. 
theme.[9] An example of such a situation, typical of Seidl's movies, is the prayers from Jesus, You Know (Jesus, du weisst, 2003).

Besides the above-mentioned models of documentaries, the influences of Nichols' reflexive and performative modes can also be observed in Seidl's works. The first of these deals both with the problems of the historical world and their representation.[10]Nichols claims that "the reflexive mode is the most self-conscious and self-questioning mode of representation." [11] This primarily involves alienating the viewer by means of varied "traps", which question the credibility of the documentary form, "instead of seeing through documentaries to the world beyond them, reflexive documentaries ask us to see documentary for what it is: a construct of representation." [12]Filmmakers often try to achieve an effect akin to the "alienation effects" described by Bertolt Brecht. Seidl also applies various distancing techniques. He rearranges the rooms where his films are shot, portrays people who can be considered outsiders and freaks, and uses extremely long, static shots. In effect, in each of Seidl's films one can find a whole series of shots which resemble tableau vivants. However, Seidl does not try to bring up the issue of the authenticity of realistic representation in his films. Questioning the credibility of the film's subjects seems much more important to him.[13]

According to Nichols, the performative model "emphasizes the subjective or expressive aspect of the filmmaker's own engagement with the subject and an audience's responsiveness to this engagement. Rejects notions of objectivity in favour of evocation and affect." [14]Performative documentaries are often made from an author's personal point of view, which favours autobiographical motifs. When it comes to the choice of subject, the performative mode often focuses on underrepresented or misrepresented social and ethnic minority groups. To a certain extent, Seidl's films are connected to this type of documentary. He presents his films' subjects from a subjective point of view. At first sight, these seem to be absolutely ordinary people, but little by little they reveal features and opinions which lead viewers to label them as members of a specifically comprehended minority group - as freaks. This is the case, for example, of Rene Rupnik, who appears in two of Seidl's films - The Bosom Friend (Der Busenfreund, 1997) and Paradise: Faith (Paradies: Glaube, 2012). A seemingly ordinary mathematics teacher still lives with her mother in a flat cluttered with piles of magazines and is an obsessive fan of Senta Berger.

Two types of documentaries from among the models distinguished by Nichols are not represented in Seidl's works. The first of them - the observational mode - attempts to avoid any intervention in what happens in front of the camera. It assumes the author is attempting to influence the filmed reality as little as possible. Many of

[9] Cf.: F. Lamp, op. cit., pp. 17-18.

[10] Cf.: B. Nichols, op. cit., p. 125.

[11] Ibidem, p. 127-128.
[12] Ibidem, p. 125.

[13] Cf.: F. Lamp, op. cit., pp. 19-20.

[14] B. Nichols, op. cit., p. 34. 
Seidl's films refer to this mode through a lack of commentary (in both options mentioned by Nichols - the voice-of-God commentary, when one can hear the speaker, but never see him, and the voice-of-authority commentary, when one can both see and hear the speaker[15]), but in all of them, the interventions of the author in what takes place in front of the camera play a fundamental role, and staging is among the basic techniques used by Seidl.[16]The other model that Seidl definitely rejects is the expository mode. Expository films attach particularly great importance to commentary. Images play only a supportive role in them: "they illustrate, illuminate, evoke, or act in counterpoint to what is said." [17]Seidl does not use the commentary because he sees in it a kind of infantilization of the viewer.

In the works of Seidl, one can find elements of most of the documentary modes distinguished by Nichols, but at all stages of his artistic career, they have coexisted with methods that goes beyond typical documentary practices. Among these, one can mention the director's far-reaching interventions in such elements of the filmed reality as scenography, lighting, and the behaviour of the characters. Theoreticians often define documentary film as a partially uncontrolled genre. For example, David Bordwell and Kristin Thompson write as follows:

It is true, that, very often, the documentary filmmaker records an event without scripting or staging it. For example, in interviewing an eyewitness the documentarist typically controls the final editing of the images, but the filmmaker doesn't tell the witness what to say or how to act. The filmmaker may also have no choice about setting or lighting.[18]

Seidl himself declares instead that work on the set of his films looks different. He often decides at his own discretion to change the furnishings in the rooms where the depicted subjects live.[19]Lamp describes in detail a way of creating space in Seidl's films, bringing into focus his attention to lighting, which plays a fundamental role in this process. When it comes to scenography, three tendencies are particularly noticeable: the joy of kitsch (especially in the interview scenes), the aesthetics of ugliness (these shots are often taken without any source of artificial lighting - especially in Animal Love (Tierische Liebe, 1996)) and images of a false idyll (characteristic of these are bright rooms, brighter than in reality).[20]

An another important method in this context, one which has been used by Seidl since the beginning of his career, is staging. He often tells the filmed persons how to act or what to say; there are rehearsals, and scenes are reshot. In contrast to other documentary filmmakers, Seidl does not hide his interventions in that what happens in front of the camera. So many scenes in his films are produced in this way that

[15] Cf.: B. Nichols, op. cit., p. 105.

[16] Cf.: F. Lamp, op. cit., pp. 16-17.

[17] B. Nichols, op. cit., p. 107.
[18] D. Bordwell. K. Thompson, Film Art: an Introduction, McGraw-Hill, New York 2008, p. 339.

[19] Cf.: F. Lamp, op. cit., pp. 85-88.

[20] Cf.: ibidem. 
they dominate the others, and lead to confusion among the viewers, who are unable to distinguish staged from unstaged scenes.

In an interview for the magazine Revolver, Seidl describes in detail work on Dog Days, the first of his films considered by critics to be a feature film. It is noticeable that the techniques used in the realization of this film are not significantly different from those applied during work on his earlier works. In the case of Dog Days, this increases the importance of the screenplay. However, it still is not a typical feature film screenplay because it does not include any dialogue. Furthermore, it is based on real people and events. Seidl gathered the material for this film over many years. For the first time, he employed professional actors, though their function was limited. They only provoked specific situations, and their development was based on the reactions of amateurs. Examples of scenes realized in this way are the conversations between the hitchhiker (played by Maria Hofstätter) and various drivers. Seidl described them as follows:

I hired extras with their own cars. They only knew that they have to take the hitchhiker. [...] Their task was simple - they had to react, as they would do that in real life. [...] Of course my goal was to arouse conflict in the scene! I knew the people, who was sitting in the cars. I had talked to them a little in order to know, who they are. I told this Maria, so she could invent how to provoke a conflict.[21]

From the above-mentioned examples, the results of Seidl's work can be seen as the consistent development of his own concept of cinema, one which resists distinctions between feature and documentary film. The Austrian film director combines in variable proportions techniques which are typical of both genres, though his films remain quite homogeneous in terms of their form. If one wanted to stick to the arbitrary division between the two stages in his career (documentary till the realization of Dog Days, and fictional after 2001) often discerned by critics, it is difficult to make any particular distinction in his work without having previous knowledge of what work on the set of Seidl's films looks like.

Manfred Hattendorf analyses in his book Dokumentarfilm und Authentizität. Ästhetik und Pragmatik einer Gattung the fictional and non-fictional elements in documentary cinema, and tries to describe the mutual relations between documentary and feature film. For this purpose, he uses the term "authenticity", which helps him to clarify the accumulated questions relating to the border area between these two types of film. He describes the semantic range of the word, using such terms as "credibility", "genuineness", "truthfulness," and giving the contexts in which it is used (e.g. law, theology, and philology). Hattendorf remarks that there are two possibilities for relating it to the film, and formulates two definitions. He writes as follows:

[21] Ch. Hochhäusler, "Die Methode Seidl”, in: Revolver: Kino muss gefährlich sein, ed. M. Seibert, Verlag der Autoren, Frankfurt am Main 2006, p. 330. 
(1) "Authentic" refers to the objective genuineness of events, which are depicted in film. Guarantee that the occurrence is authentic implies that filming didn't influence depicted event. The authenticity is grounded in the source of depiction.

(2) Authenticity is a result of applying cinematic techniques. "Credibility" of depicted events depends on the influence that the cinematic strategies exert on viewers. Authenticity is grounded equally in form and in reception.[22]

The second definition offered by Hattendorf can be used to characterize the works of Seidl. It can be useful in describing their formal homogeneity and the impression of "genuineness" they make on the audience, without categorizing the applied methods as documentary or fictional.

Hattendorf enumerates techniques which are used to intensify the impression of the authenticity of footage. These are connected with such elements as dialogues, camera work, sound and music, editing, self-reflexive elements and mise-en-scene.[23]

According to Hattendorf, dialogues in a local dialect or jargon are elements that particularly intensify the authenticity of a movie. Seidl also characterizes his film subjects through their language. The Ukrainian immigrants in Import/Export (2007) or Arabs in Good News speak with foreign accents, use only basic vocabulary and simple grammatical structures, whereas the native-born Austrians speak Viennese German. In both cases, language reveals a character's descent and stresses social divisions.

In terms of authentication methods related to editing, one can observe that in Seidl's films the footage is structured in chronological order. The Austrian director does not use flashbacks or flash-forwards. He very often follows the principle of unity of place or time. For example, the plot of Good News is limited to one day from the life of Viennese outsiders - Arab immigrants or patients in the geriatric department of a hospital. In the opening scene, we observe newspaper sellers going to work at dawn, and at the end of film we see them still standing on the streets of Vienna although night is beginning to fall. In Jesus, You Know, in turn, the depicted events take place in a single building - a church.

The effect of authenticity in Seidl's films is intensified also through the lack of commentary and nondiegetic sound and music. The creation of space also fulfils a very important function. As a concrete example, one can point to the means of depicting the home of one of the characters in Animal Love, a man who begs for food for himself and for his pets. His "flat" falls into ruin, and is located in a dark, unheated basement. The authentication consists in the lack of any form 
of aestheticization of this place. The lack of additional light sources makes these rooms even gloomier.

When it comes to the actors' performance, an impression of authenticity is intensified through the engagement of the non-professional actors. Seidl hires amateurs, who, as he says, "play the role of their own lives."[24] Their life experience is supposed to provide a guarantee of credibility. Another method, used for example in Dog Days, is provoking certain situations and observing their spontaneous development. The effect of authenticity in Seidl's films often results from scenes being shot in static takes, in which the subjects talks about the most intimate aspects of their lives. This is the case in Jesus, you know. While watching the film, we can hear the characters speak in confidence about their family life, sexual experiences, and failed relationships.

Another technique often used by Seidl, and which also gives credibility to his films, is combining two types of shots. To the first type are short, shaky takes in which the camera follows the subjects. In this case, viewers have the impression of being participants in the actions presented. Seidl applies this kind of shot in the beginning of Dog Days to present a violent argument over a woman in front of a club, and then to portray an alarm salesman wandering door to door. Used equally often in Seidl's films are very long static shots. These provide a reference to observational documentaries, and for this reason give the impression that the scenes presented were shot without any outside intervention, which seems to offer proof of their objectivity. What happens on the screen is also not without significance. For example, in Jesus, you know we can observe the prayer of a young man, who relates his erotic fantasies and confesses that he cannot refrain from watching pornographic films. In Animal Love, the same static camera is used instead to shoot a couple having sex, and a man exchanging passionate kisses with his dog. The fact that Seidl's observations cross the boundaries of the subjects' privacy or bring up taboo subjects places the viewer in the position of a voyeur. The authenticity of his films also has something in common with misbehaviour because it arouses the viewer's conviction that he has witnessed something that should remain hidden from others.

In the essay Visual Pleasure and Narrative Cinema, film theoretician Laura Mulvey describes the scopophilic pleasure of looking that cinema offers to viewers. The term "scopophilia", derived from Sigmund Freud's Three Essays on Sexuality, denotes an element of sexual desire connected with "taking other people as objects, subjecting them to a controlling and curious gaze."[25] The examples given by Freud focus on the various forms of voyeuristic activities engaged in by children, but this instinct does not disappear in later development, although it is

[24] M. Frey, "The Possibility of Desire in a Conformist World: The Cinema of Ulrich Seidl', in: New Austrian Film, ed. R. von Dassanowsky, O.C. Speck, Berghahn Books, New York-Oxford 2011, p. 189.
[25] L. Mulvey, Visual and Other Pleasures, Indiana University Press, Bloomington 1989, p. 16. 
modified by other factors. In some extreme cases, it can become a perversion. Mulvey uses this term to characterize cinema as an institution based on satisfying the voyeuristic fantasies of viewers. Mulvey focuses on analyses of classical Hollywood films and the narrative conventions applied in them in order to create "a hermetically sealed world which unwinds magically, indifferent to the presence of the audience, producing for them a sense of separation and playing on their voyeuristic phantasy." [26] The pleasure of the audience derived from watching the film is additionally intensified through the star system. The presence of admired actors activates a process of producing "ego ideals", in which "the glamorous impersonates the ordinary".[27]

The cinema of Ulrich Seidl can also be seen as a fulfilment of the voyeuristic fantasies of the audience, although it makes use of other solutions than those described by Mulvey, and the pleasure of the viewers results from different processes.

Even the formal aspects of Seidl's films evoke the situation of peeping on somebody. One of the most commonly types of takes applied by Seidl is a long or medium-long shot from a static camera placed opposite to the filmed subjects, an example of which is the striptease scene from Dog Days. In this scene the widower's domestic help impersonates his deceased wife. On the day that falls on the birthday of his beloved, she dances and undresses herself in front of the man. The camera is located behind the older man's back, and because of the great depth of field, we can see the entire room. The scene depicts a very intimate moment in the life of these two human beings. Furthermore, showing older, obese, or unattractive persons as erotic objects is rare in cinema. All this contributes to the impression that our participation as viewers in the presented event flagrantly violates somebody else's privacy. The fact that the picture is static and the whole scene consists of one long take distances the viewers. The cold, behavioural observation does not favour the process of identification or arouse sympathy for the characters. The pleasure that the viewer derives from watching scenes like this consists solely in an emotional separation from the film's characters. Depicting events from this perspective places the viewer in the privileged position of an uncommitted observer, and enables him to dispense justice or even to hold the subjects in contempt.

In his book Poetyka kina dokumentalnego, Mirosław Przylipiak describes filming with a hidden camera as "an eye of 'Big Brother', God, who is convinced of the sinful substance, or at least double-face, of human nature." [28] He writes that the advantage the audience has over the subjects is similar to God's advantage over man. The difference lies in the fact that God is merciful, and observing human beings does not

[26] Ibidem, p. 17.

[27] Ibidem, p. 18.
[28] M. Przylipiak, Poetyka kina dokumentalnego, Pomorska Akademia Pedagogiczna. Wydawnictwo Uczelniane, Gdańsk-Słupsk 2004, p. 172. 
give him satisfaction, while people are often pleased with disclosing the weaknesses of others. The characters in Seidl's films are shown from a similar perspective - that of Almighty God. It depends only on the viewer if he decides to be merciful, and if he, like the director, will be able to see tenderness in the picture of an older woman performing a striptease.[29]In spite of everything, there still exists the possibility of viewing these films in such a way.

[29] Cf.: "A lonely man, a widower tells his domestic aid to undress herself, and she dances. Some people consider it embarrassing because she is an older woman, isn't very shapely. And it is a tenderness to me." A. Kuźniak, Pornograf, <http://wyborcza.pl/ duzyformat/1,127291,7819059,Pornograf.html $>$ [accessed: September 16th, 2013]. 

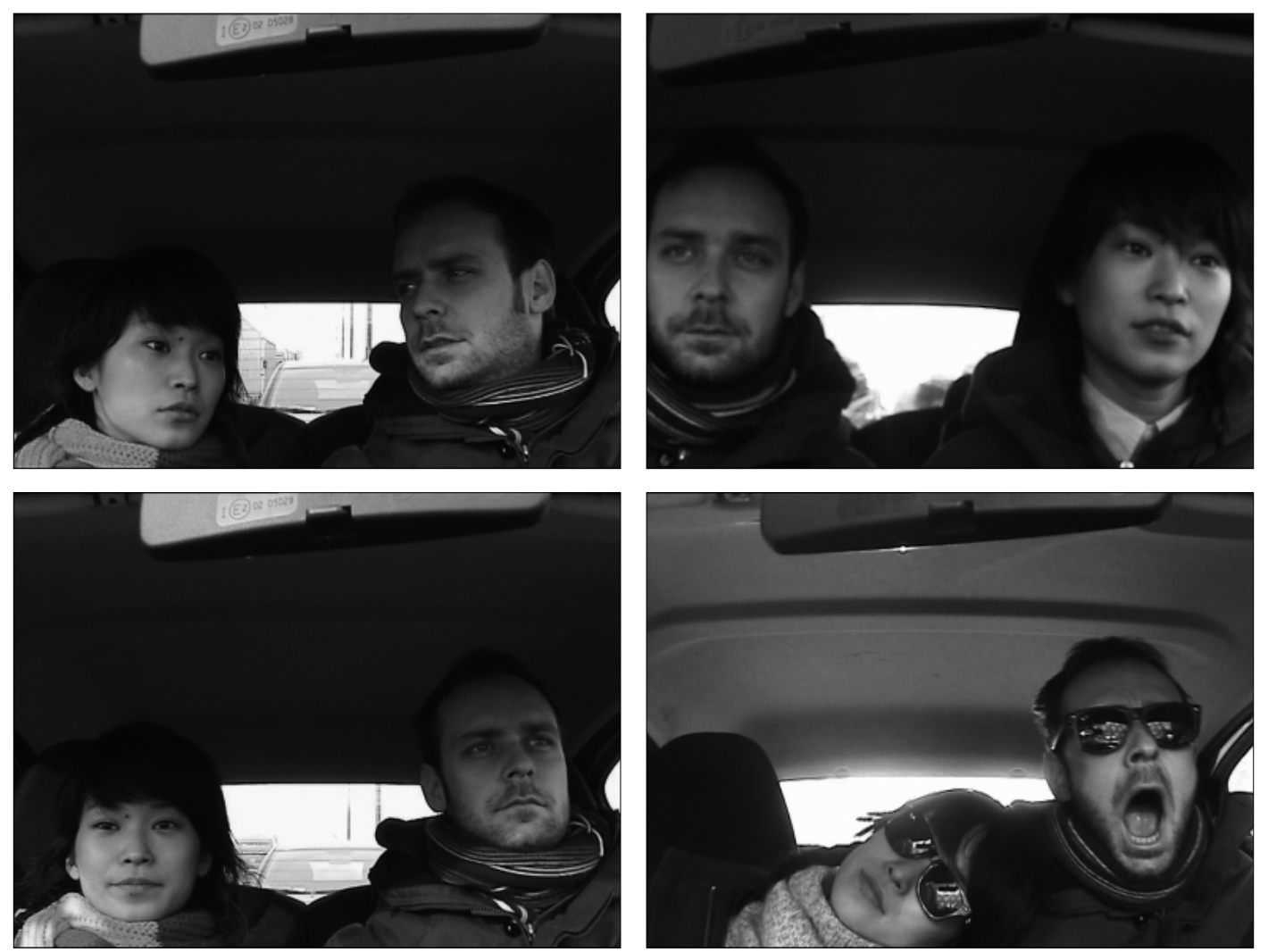

Self(less) Portrait, dir. Matej Bobrik,

prod. Polish National Film School in Lodz, 2012 